\title{
Consideration on Ethical Education
}

Viera Bilasová, Gabriela Platková Olejárová

\begin{abstract}
The present paper responds to the current ethical challenges facing education. The authors consider the issues, methods and challenges associated with the innovation of current ethics education. It is expected to effectively contribute to raising young people's moral awareness and ethical literacy including also economic literacy and its ethical aspects. The authors emphasize the importance and humanistic mission of ethics education which requires philosophical anchoring. This is based on the development of reflective thinking, which both strengthens students' intellectual, psychological and moral growth and helps develop their own desire to learn and to gain knowledge. The cultivation of young people's behavior presupposes a type of ethics education and training that will significantly develop the skill to judge and act morally in their professional setting. It includes updating the methods of teaching ethics, the aim of which is to enhance young people's personal development and value orientation and, at the same time, it is also a challenge for teachers and teacher training institutions.
\end{abstract}

Key words: Ethics, economy, education, methodology, reflective thinking

\section{Introduction}

Each period has its peculiarities bringing many changes and there is no consensus to which direction these changes are going and where they are heading. "We live in a world of 'moral capacity inflation', in a world threatened by fundamental disorder; in which all society members feel morally virtuous, or in which they all approach their own vices as negligible" (Plesu, 2001: 13). This consideration is, in fact, a challenge to critically reflect on the forms of morality in today's world and the ability of contemporary man to reflect on it ethically. All of us search for 'grains of good' in the depths of every human being and recognize the forms of evil, but not all of us can appeal to our conscience and decency in everyday life, especially in relation to other people. The issue under consideration is highly up-to-date regarding the young people, their upbringing and education for their future.

Finding one's place in life during this difficult period (current pandemia) is not an easy project for young people. It is very difficult to state unequivocally what a right or good conduct is and how to respond to relativizing or marginalizing morality throughout life which assume that the roots of the crisis pertaining to people's behavior stem from the quality of education and of the education methods applied. The type of education, its methods and contents are an important factor in the education of young people, including the instruction in ethical literacy, which provides them with the ability to morally judge and act independently. Education process is a mediation toll providing a young person with the ethical implications of current social problems. The importance of ethics education at school has been recently highlighted and its forms in the period of developing new communication technologies, become highly demanding both with regard to teacher training, and to developing students' ethical competence.

The dynamics of social change has fundamental impact on the way of life and its meaningfulness, as well as on recognizing the importance of the value background and morality present in each society and/or culture. Ethical topics come to the forefront of young people's interest and force them to explore their value content and to seek a certain moral consensus in

prof. PhDr. Viera Bilasová, CSc., Prešovská univerzita v Prešově, Filosofická fakulta, e-mail: viera.bilasova@ unipo.sk doc. PhDr. Gabriela Platková Olejárová, Ph.D., Prešovská univerzita v Prešově, Filosofická fakulta 
insisting on their individual goals in the family, at school, among friends and in the society as a whole. School is facing new demands and challenges since the type of education, its methods and content are expected to contribute in a desirable way both to the development of quality education and to developing and raising young people's moral awareness. Conventional education and traditional forms of education models provoke discussions and disputes about the nature of modern education. The mainstream approach emphasizes the training of pupils for their future professions, often at the expense of enhancing their personal and moral qualities. Recently educators are under pressure, since training technical and economic skills is foregrounded, without a deeper interlinkage with moral personal qualities inevitable for every future professional and a good citizen.

\section{Methods}

The research methodology of the present study on the innovation in ethics education comprises the reflective thinking method deploying the critical analysis of the teaching-related experience. Nevertheless, the discussion on the need for innovation and advancement of ethics education draws also on empirical research conducted in the Slovak secondary school setting. The aim of the present study is to clarify and determine how the subject of ethics/ethics education is implemented, approached and critically viewed by educators in order to propose possible quality-education-targeted modifications in the subject curriculum. Drawing on the assessment of data obtained from the empirical research with the use of questionnaire technique, several implications and proposals for modifying the teaching methodology in schools were designed.

Drawing on the empirical research data, the need for a deeper theoretical analysis of interdependence between the ethics education philosophy and the ethical aspects of economic education was identified. The aforementioned mutual interdependence was approached critically in terms of examining the internal and external impact factors. Subsequently, the method of synthesis was used in order to apply the research findings in proposing the methodology of innovating the ethics education in schools with an impact on social and professional practice.

\section{Ethical aspects of economic education}

A gap has been created between economics and ethics, which Amartya Sen also considers to be one of the major methodological shortcomings of contemporary economic theory (2002: 7). In the current era of economic prosperity, ethical judgments are not only instrumental in their very nature, but they have been present in everyday decision-making in crucial situations as part of social action. Educational practice is vital for educating and upbringing young people in order to cultivate their economic (including financial) literacy for competent decision-making and acting. It is important to realize that ethical leadership (knowledge and skills) is an inevitable toolkit for every pupil or student, as well as a future manager, economist, HR specialist, lawyer, etc. Every profession requires at least an ethical minimum, because legal norms are often insufficient and not everything that is considered legal is in fact evaluated as morally acceptable. Justifying the importance of ethics in education is therefore mandatory. Consequently, the following questions arise: Is ethics education a part of economic education ${ }^{1}$ ? Should it be part of it?

We can hear the usual phrases of business toughness, in which there is no room for sentiment, compassion, cooperation, help, if the priority is to win in competition and become successful.

\footnotetext{
${ }^{1}$ The importance of ethical education of future professionals in individual professional areas is addressed by several authors (eg Martinkovičová, 2014; Fobelová, 2013; Janotová, 2005; Bláha-Dytrt, 2003, Seknička-Putnová, 2007; Holátová, 2002 and others) emphasizing different approaches and methods as well as priorities in ethics education.
} 
However, ethics is always inherently present in economic life, even if rejected by businesspeople. How can we explain the conclusion of business contracts (based on word of honor and faith in keeping one's promise), or the ever-expanding manifestations of corporate social responsibility? Is it just an instrumentalization of ethics in the business world or a truly selfless ethical motivation and entrepreneurs' acts? Companies are social institutions to be approached as parts of a broad society, thus supporting well-being through their agency. They are not static; rather they are entities permanently interacting with the immediate and broader setting and culture. Companies are thus co-responsible for shaping the society with which they are interlinked and in which they operate (Verstraeten, 2000, p. 3-7). Therefore, ethics education and development of future managers' and entrepreneurs' ethics competencies is desirable as far as their decision-making and agency directly impact other people's quality of life (job creation, contributing to the country's wealth, innovation, environmental concern, promoting social justice). The role of the profession lies mainly in fulfilling its social goals with an emphasis on the positive development of society. The above stated profession-related objectives argue in favor of ethics education of professional managers.

However, the ethics education of future managers and economists may clash with a lack of interest manifested by the managers themselves. Experts are presumed and even expected to be able to pursue their professional agency in accordance with the values and norms observed in a given society, so the prevailing view is that they do not need any special ethics education knowledge of ethical professional norms and values. In conflict situations, they tend to act intuitively, habitually. They argue that they do know what it means to act honestly, responsibly, fairly, etc., but that does not mean that they know or understand what role ethical values or principles have in exercising their professional agency. Although they professionally perform an economic analysis of an issue, they may encounter difficulties describing its ethical aspects. However, ethical issues are inherently present in business and ought to be addressed in a sensitive and specific manner. Therefore, ethics education of future professional managers is inevitable in order to ensure the acquisition and development of ethical skills to recognize the issue as ethical in its nature, to distinguish what is correct and what is incorrect, to name values, to make proper moral judgments and decisions. It is necessary to develop and enhance the ethics education of future managers and economists, both within courses in business ethics or managerial ethics and in higher education, including the education in economic and financial literacy. The advantage of ethics education lies in "recognizing" the ethical dimension of the issue and in critically assessing and in conducting the ethical analysis in order to find the appropriate solution ${ }^{2}$.

\section{Ethics and school}

Most of the considerations and opinions manifested in the ongoing discussions and debates about the forms of school education agree on the need and importance of ethics in school training. The fundamental question in Slovak schools that arises in the discussions is what kind of ethics and in what way it ought to be taught at schools. Finding a suitable "model" including the type and forms of instruction also presupposes a dialogue with culture and the value background, which is reflected in more specific national educational programs or subject curricula. In addition, the experience with applying various methods of education differ and, therefore, it is currently necessary to respond to this difference and to innovate the methods, both in terms of the nature of instruction and the status of ethics or ethics education as part of the whole process of education. The present paper draws on Slovak educators' experience and contribute to the ongoing discussion on the issues of teaching ethics, the mission of schools and

\footnotetext{
${ }^{2}$ Martinkovičová (2014) offers an inspiring definition of the managers-targeted content in ethics education with regard to social entrepreneurship.
} 
the degree of their responsibility for ethics instruction of young people. In a democratic society, the importance of the issue is manifested especially in university ethics training of future teachers who face the challenges of contemporary school intended for young people's moral consciousness and morality development.

This reflection on the forms of ethics education in contemporary school makes it possible to contribute to the discourse comparing educational experience nationally and internationally. The arts of teaching and learning have been one of the pillars of education since the beginnings of this civilization, which led it to a form of independent and critical thinking. While until now there were paradigmatic contours of approach to the world and understanding of human's place in it, including certain moral pillars, we must now respond to pluralism and relativization of moral values, inflation of ethical competence and moral indifference to many current issues. The cultivation of young people's behavior builds on education aimed at value identification and intended to provide an individual with the skill to judge and act independently. The above may be understood as a challenge for innovation and modernization of ethics education.

Educators' experience supports the premise that there is no universal model or "recipe" for ethics education in school. There are numerous differences and of factors (national, cultural, institutional and other) influencing the choice of its content and methods. At the same time, the status of ethics varies, it may be compulsory, optional or elective. In the search for the optimal way of teaching ethics, foreign teaching "models" cannot be adopted despite being effective in different cultural conditions, however, it is not necessary to overestimate the national idiosyncrasies either. The possible innovations in institutional ethics education result from the general principle stressing that the system of education and its quality are rooted in ethical criteria (school policy, education strategy, teacher status, pedagogical agenda, etc.) defining school as an "ethical institution" (Sttarat, 2012: XI.) Educators generally perceive the presence of ethical aspects in the educational activity as an inherent part of their professional approach. A teacher's integrity together with the ethical nature of school instruction forms the basic framework for cultivating pupils' behavior. However, the general framework of the education process requires that specific attention be paid to personal development, ethical thinking and ethical ways of thinking including its application in real life. This goal is met by a special subject of ethics education/ethics, the inherent part of which is economic and financial literacy.

The education process thus becomes a tool for formation and acquisition of ethics competence - an important component of each individual's toolkit. General intelligence, the ability to think analytically, and emotional intelligence, the ability to deal with social situations, are complemented by ethical intelligence, the ability to do good (Einhorn, 2005: 15). Young people seek answers to many complex questions affecting their way of life, the definition of their own identity, their personal and social status, they strive to understand the moral dimension of their decisions as the key issues in their life orientation. Even for an adult, it is not easy to grasp the moral dimension of various life situations and evaluate them correctly. During the adolescence searching for one's identity is a complex process of paramount importance resulting in maturation during which a young person tries to take freedom and their life into their own hands. It is an arduous process accompanied by searching, confusion and uncertainty in orientation not only in relation to oneself but also in relation to others: "A young person does not only want to know himself/herself, to know what he/she can endure, one is to assert his/her identity in accordance with some kind of conviction and / or life program" (Říčan, 2004: 171). Acquisition of ethical skill of recognizing and correctly evaluating moral facts is one of the skills developed in the education process and is an important feature of young people's personal development and its potential application in their social and professional life.

Enhancing the status of ethics education in the system of humanities appears to be a fundamental step, especially in the education of adolescents in secondary schools in Slovakia. 
Regarding young people's moral maturation, adolescence is the most complicated period, but at the same time a period playing a critical role in developing personality and its ethical literacy. This standpoint is evidenced by empirical data yielded by research conducted by a team of scholars focusing on the training of future teachers of ethics education. The majority of secondary school teachers ( $80.5 \%$ respondents) consider the introduction of ethics education as a compulsory subject a mandatory measure. Research ${ }^{3}$ findings indicate that the complexity of the secondary school setting requires a particular approach and methodology. Instruction based on the considerations balancing rational and value approach to actual moral issues is currently considered to be a good educational practice. Only in this way ethics education can become a part of the life lesson illustrating how to treat others and how to enforce the principle of "being a good person".

\section{Philosophy of ethics education}

The main objective of teaching ethics in schools is to help young people find their place in life and develop their ability to take a "human" attitude, which also helps balance their own ambitions and responsibilities to others or the community, in other words, to educate an individual with their own identity and value system. In the Slovak educational system, ethics education is perceived as an educational-psychological way of developing basic social skills in students (resulting in pro-social behavior) and teaching students how to be polite and good to others. I dare venture that despite instruction in pro-social behavior being a basic and a major component of ethics education, especially at primary level, this subject cannot be reduced merely to training in appropriate behavior. At school pupils are instructed how to become a better person, however morality and responsibility cannot be limited to acquiring competences and skills. Morality cannot be taught through adopting predetermined moral rules and norms. Through instruction, students can be trained in how to think independently, critically and creatively and how to make decisions with responsibility, especially when they need to apply moral considerations in everyday life situation. Each system of education has its moral implications, which are accompanied by pupils' effort to understand the rule or norm and, at the same time, have their own opinion, which is accompanied by an understanding of the consequences of their decision, including their moral responsibility. From an early age, a young person needs to know the reasons for what they are required to do, which relates to their desire to know why to think, and act like in this or that way (Hábl, 2015: $81-84$ ).

The emphasis on teaching obedience may have been included in old approaches to education, but its importance cannot be ruled out even nowadays. Another extreme seems to be the overestimation of the role of the cognitive aspect in educating pupils as a kind of theorizing detached from their daily life and their challenges, considered as a methodological onesidedness in education. Treating young people as copies of adults meets neither their needs nor the demands that they will face in real life and does not provide them with adequate life lessons on how to behave; in addition, adults may not always set positive examples in applying ethical values.

The ancient Greeks and Romans understood that education plays a major role in "the arts of living," and it is not a scheme. Moral education is philosophy-based on the approach to reality as a whole, its value foundations and, above all, it is accompanied by a rational effort to

\footnotetext{
${ }^{3}$ The aim of the research on the training of future teachers of ethics education (Institute of Ethics and Bioethics of the University of Prešov, Slovakia) was to establish the state of affairs, implementation and teachers' opinions on possible updating of ethics education. Empirical research has confirmed that the complexity of the secondary school setting requires ethics education to be a separate subject and a specific approach and methodology ought to be applied in the instruction. At the same time, it proved the need for a thematic update of economic issues in terms of their ethical aspects (Balogová, 2019).
} 
understand this way of reflection. Ethics is primarily a philosophical discipline, the subject of which is the study of morality. It is a way of exploring how we treat others, how we view the world, and it discusses the art of being a good person. In education, it is necessary to learn what can be known, and this requires a balance of cognitive activity (ethical knowledge) with moral education (behavior) ${ }^{4}$. Especially in secondary education, answering fundamental theoretical questions, such as what good means and what a good (fair, happy) life is cannot be avoided. One can only agree with the view that these are questions of meta-ethical nature which precede any practices and require a philosophically rooted way of thinking. Without justification and adequate reflection, they do not get any feedback and result in a loss of normative distinction between good and evil in theory and practice, usually leading to a loss of clarity and distinctiveness, and the fogging of ethical terminology (Hábl, 2015, p. 79). Ethics belongs to life and as a theory it cannot replace real contexts. Although moral issues are not solved with a "pen in one's hand" (Plesu, 2001: 103), their complexity and urgency often require the assistance of theoretical assessment and ethical argumentation. The ability to speak about life using the language of ethics is linked to an ability of ethical knowledge and to the ability to choose between pluralistic values, to which the education of ethics can contribute, especially regarding adolescents.

Prosocial behaviors can be observed also in economic relationships. Moral norms permeate human life and are naturally integrated into economic or market relations. These are inherently present in interpersonal relationships involving, on the hand, friendship, cooperation, help, compassion, and, on the other hand, hostility, conflict, various disagreements, indifferent behavior, arrogance, etc. Moral agent's economic relations are merely one of the various types of social relations. Within the framework of economic (market) relations (and broader social relations) moral agent is subject to certain laws operating in this relationship. Within economic relationship agency is practiced through purposeful-rational acts (in which the agent rationally considers and selects the means of his/her action with regard to achieving the set desired goal). Moreover, the agent focuses on the needs, acts, interests of all other agents potentially interested in economic exchange of goods, assets, services, etc. Naturally, a specific type of motivation is determined by the way in which a relationship is experienced. Economic relations are closely linked to a certain way of being a human, the main goal of which is primarily to make a profit. The economic agent has the right to make a profit, which is the main reason for conducting business and is considered an important factor and the main criterion for assessing the company's success. However, this right to profit does not in any way mean exclusively focusing on the economic agent's own interests, i.e. it does not exclude any moral requirements for helping others, for cooperating, respecting others' interests, caring for other people's well-being and quality of life, especially those whose lives are affected by the economic agent's actions and decisions. In this context, the ethics education targeting managers emphasizes the role of economy - its goals or services - thus building up the framework for economic activity assessment. Economic relations always result from the actions of an individual (entrepreneur,

\footnotetext{
${ }^{4}$ Reflexivity of thinking and its development is possible and, moreover, necessary for students in primary education. This methodology is based on the educational concept of Philosophy for Children (Lipman, 2003), which has its roots in the pragmatic tradition and in the development of its main idea of the primacy of reflective thinking in education as a way of research (John Dewey). These approaches are shifted more to the methodological level of shaping children's thinking habits (skills) both accelerating their intellectual and psychological growth and developing their desire to learn as a desire for knowledge and research. It is a kind of "small multiplier of philosophizing" (Zoller, 2012) in ethics classes, which consists in the methodology of creating enough space for dialogue (Socratic method), the atmosphere in the classroom supporting questions, expressing one's own opinion or a critical approach. This way of thinking and working in the lesson makes it possible to uncover connections and understand their moral significance in life situations, to address issues in ethics language, and thus to gradually incorporate them into one's own moral convictions.
} 
manager) who consciously acts, makes decisions with a certain intention. Ethics education of future entrepreneurs and managers does not involve only the development of effective social skills, it also cultivates the ethical ability to make moral judgments, make decisions and to act - and to be able to justify to oneself and others (stakeholders) why one acts in certain way. This is intended to bring systematic and targeted ethics education hand in hand with economic education.

Should we preserve the autonomy of children, or to develop their character, to strengthen their ethical knowledge through the cognitive component of the education process, or to allow for their self-expression? Or should we accept that children need standards, clear guidelines, receptive adults firmly insistent on responsible behavior? However, a resolute adherence to standards has been out of fashion in education circles for more than thirty years (Sommers, s. 35). These are questions to which ethics in school setting had to seek an adequate answer, even in terms of societal interest.

\section{Results}

If we return to the original question of what kind of ethics to teach and how to incorporate it into the education process, we will not find a clear answer. Each of the models developed within the education systems brought some experience and methodological enrichment, including the identification of their weaknesses. The general aspects of the experience base of ethics education include the philosophical anchoring of the subject. Its task is to develop the natural need of each individual, their rational orientation in life, and this can only be philosophical. Ethics education can be supported by the development of thinking, the formation of competencies aimed at strengthening authenticity, the involvement of the whole personality in agency supporting independence, self-confidence and practical attitude to life situations. Having one's own opinion or having life in one's hands means gaining control over both external and internal influences. Children are vulnerable, and it depends on age and level of maturity how they can do things right and reframe their own lives in order to shift the locus of control (Alexander-Sandahl, 2020) from the outside to the inside. Therefore, ethics education is an important factor supporting moral and personal maturation of children and young people. Creating an inner moral "compass", knowing one's own emotions including empathy for others, cooperation and the need for communication, motivation and one's own scale of values do express self-reflection and strengthen self-confidence and self-esteem without overestimating individuality, uniqueness or performance.

Another productive factor enhancing the moral consciousness formation in Slovak school system is active dialogue and cooperation with other subjects as an educational strategy based on the interdisciplinary connection of ethics education with other subjects enabling education effectiveness and its interlinking with real life. Knowledge acquired in other subjects reinforces the belief that learning enables uncovering the differences and similarities of assessments based on the morality in young people's life. Coordination of approaches of school subjects to reality in cooperation with a moral approach, contributes to the development of competencies and skills of young people to find their way and prove their worth in life, sometimes even to survive in today's reality and be able to promote their own interests and goals.

Each methodology assumes that it is not possible to create a uniform or universal education pattern for moral behavior. The knowledge transfer and teaching are processes that motivate and develop one's own desire to know and learn how to look for one's path together with the selected teaching method. In terms of educational impact, the teacher plays a key role in this process. The teacher becomes an agent of ethics education, for whom moral questions always remain alive and open, he/she is in contact with young people, he/she takes their problems and questions seriously and builds their trust in the process of finding answers together. In 
particular, the complexity and nature of new social moral dilemmas (development of information and communication technologies, ethics in the economic and political sphere, social inequality, globalization, terrorism, eco-consumption, sexual liberalism, hedonism, individualism, etc.) place increased demands on teachers, many of them having not encountered these issues yet. Currently, also a growing need to address current issues ${ }^{5}$ in economic and bioethical education can be observed. The majority of experienced teachers can combine and modify educational methods in linking them to the lesson content (topic) and adapt them to the classroom setting. The above stated confirms the proven pedagogical principle according to which only a creative teacher can form creative personalities. Although strengthening the position of the teacher in this process takes several forms (advisor, facilitator, moral authority, partner or mediator, etc.), his/her role is irreplaceable. The role of the educator is to choose the right level of knowledge transfer (cognitive background) and harmonize it with atmosphere for critical thinking in the classroom, which requires a certain "pedagogical fronesis" (Wringe 2006) enabling a reasonable and justified distinction between behavioral requirements and the validity of pupils' moral convictions. This is especially true in the current forms of distance learning in the time of pandemic, in which the teacher plays an important role, especially from the educational aspect of his/her work. At the same time, it is a challenge for the university training of ethics education teachers, who are expected to make a decisive contribution to the progressive development of modern ethics education with their expertise and pedagogical professionalism.

\section{Conclusion}

The path to the quality of education processes and pedagogical mastery is not easy or unambiguous, especially in subjects the "usefulness" or effectiveness of which cannot be directly measured or assessed. Nevertheless, in today's difficult times, it is important to emphasize the need, but also the current issues and questions related to the formation of moral consciousness and ethical competence of young people, especially in terms of humane mission of ethics education, which is growing in importance and opens new challenges for the $21^{\text {st }}$ century ethics and morals. Ethics education requires due attention, both in terms of updating its content and modernizing its forms with respect to national and global trends.

Nowadays, the priority in Slovak schools is to awaken the interest in ethics (not in its systematic interpretation) and to create the preconditions for the school of ethics that would equip the young people with moral thinking, critical thinking and ethical argumentation applicable in real life situations or actions. An ethical guide is not a command to act in a certain way, rather, it is a need enhancing appropriate orientation and a responsible approach to life and one's own actions. Moreover, it is a kind of "compass" of value orientation as it assists professionals in verifying their abilities and skills, and in identifying themselves with certain believes and life projects.

\footnotetext{
5 These are the issues related to the development of economic and financial literacy with regard to ethical responsibility for critical reflecting and acting in real life circumstances. Reflecting on and implementing the ethical aspects of business, trade or of the financial strategy and acquiring certain competencies and abilities prove to be essential and important for appropriate orientation in a young person's life in terms of his/her success (Kalajtzidis 2019). Bioethics issues are increasingly shifting from the national to the global level. They include important issues related to health care, population policy, environmental protection, environmental security, but also issues of lifestyle quality, human dignity and the ethics of sexual life. Bioethical education is aimed at knowledgeability, enhancement of bioethical sensitivity, value attitudes and critical approach to phenomena, while contributing to the overall personal and moral growth of students. Bioethical topics deserve special attention especially in the education of adolescents (Lešková Blahová, 2019).
} 


\section{References}

Alexander, J. J., Sandahl, I. D. (2020). Prečo sú dánske deti št’astné. [Why Danish children are happy] Lindeni: Albatros Media a.s.

Balogová, B. (2019). Aktualizácia výučby etickej výchovy (pohl'ad z edukačnej praxe). [Updating the teaching of ethics education (educational-practice-based approach)]. In: Viera Bilasová (ed.): Metodika inovácie etickej výchovy (pre stredné školy). [Ethics education innovation methodology (secondary schools' guidelines)]. Prešov, FF PU: 28 - 52

Bláha, J. - Dytrt, Z. (2003): Manažerská etika. [Management ethics]. Praha: Management Press.

Blahová, A. (2019). Bioetické témy v etickej výchove. [Bioethics topics in ethics education]. In: Viera Bilasová (ed.): Metodika inovácie etickej výchovy (pre stredné školy). [Ethics education innovation methodology (secondary schools' guidelines)]. Prešov, FF PU: 124 - 143

Einhorn, S. (2009). Umění být hodný. [The art of being good] Ostrava: Čintamáni

Fobelová. D. (ed.) (2013). Profesionálne etické kompetencie: profilovanie a uplatnenie. [Professional ethical competences - their development and application] Banská Bystrica : Vydavatel'stvo UMB Belianum.

Hábl, J. (2015). I když se nikdo nedívá. Fundamentální otázky etického vychovatelství. [Even though no one is watching. Fundamental issues of ethical education]. Ústí nad Labem: Pavel Mervart.

Holátová, D. (2002). „Vzdělávaní a rozvoj manažerů - cesta ke zvýšení kvality ř́zení“. [Managers training and development - a way to increase the quality of management]. In: Dytrt, Z. a kol.: Manažerská etika...inspirace pro 21.století. [Management Ethics ... inspiration for the $21^{\text {st }}$ century] $3^{\text {rd }}$ volume. Praha, Economia, pp. 63-75.

Janotová H. a kol. (2005): Profesijná etika. [Professional ethics]. Praha: Eurolex Bohemia, s.r.o.

Kalajtzidis, J. (2014). Morálne hodnoty a ich komercionalizácia v modernom svete biznisu. [Moral values and their commercializing in the modern business world]. In: Viera Bilasová (ed.): Etické zošity 1. Význam etickej teórie v príprave učitel'a etickej výchovy. [Notebooks for an ethics 1. The importance of the ethical theory in the training of ethics teachers.]. Prešov: FFPU, s. $78-96$.

Lipmann, M. (2003).Thinking in education. UK: Cambridge University Press.

Martinkovičová, M. (2014). Význam etického vzdelávania pre sociálne podnikanie. [The importance of ethics education in social entrepreneurship]. In: Lapinová, E. - Gubalová, J. (ed.): Vzdelávanie ako determinant rozvoja sociálneho podnikania. [Education as a determinant of social business development]. Banská Bystrica: Ekonomic university.

Plesu, A. (2001). Minima moralia. Bratislava: Kalligram.

Platková Olejárová, G. (2008). Aplikácie etiky sociálnych dôsledkov v ekonomike. [Applying the ethics of social consequences in economy]. Prešov: FF PU.

Platková Olejárová, G. (2014): Profesijný etický kódex - otázka motivácie. [Professional code of ethics - the issue of motivation]. In: Gluchman, V. (ed.): Perspektívy profesijnej etiky. [Professional ethics perspectives]. Prešov: FF PU, s. 33-40.

Putnová, A. - Seknička, P. (2007). Etické řízení ve firmě. [Ethical management in company] Praha: Grada.

Remišová, A. (2004). Etika a ekonomika. [Ethics and economy]. Bratislava: Ekonóm. 
Říčan, P. (2004). Cesta životem. Vývojová psychologie.[The life journey. Developmental Psychology]. Praha: Portál.

Sen, A. (2002). Etika a ekonomie. [Ethics and economics]. Praha: Vyšehrad.

Hoff Sommers, Ch. (2002). How Moral Education Is Finding Its Way Back into America's Schools. In: Bringing a New Era in Character education. Hoover Press: Damon. 2002-26, p. 23 $-41$

Starrat, P. J. (2012). Cultivating an Ethical School. New York-London: Routledge.

Zoller, E. (2012). Učíme děti ptát se a přemýšlet. Metody a aktivity k rozvoji myšlení i kultivaci osobnosti dětí. [Teaching children to ask and think - methods and activities to develop thinking and cultivate the personality of children]. Praha: Portál.

Verstraeten, J. (2000). Business ethics: Broadening the Perspective. Leuven, Peeters Publishers.

Wringe, C. (2006). Moral Education. Beyond the Teaching of Right and Wrong. Dodrecht: Springer. 